\title{
Social scientists tell Congress: 'Don't cut our funding'
}

Linguists, anthropologists and political scientists take to Capitol Hill to defend their research.

Erin Ross

14 April 2017

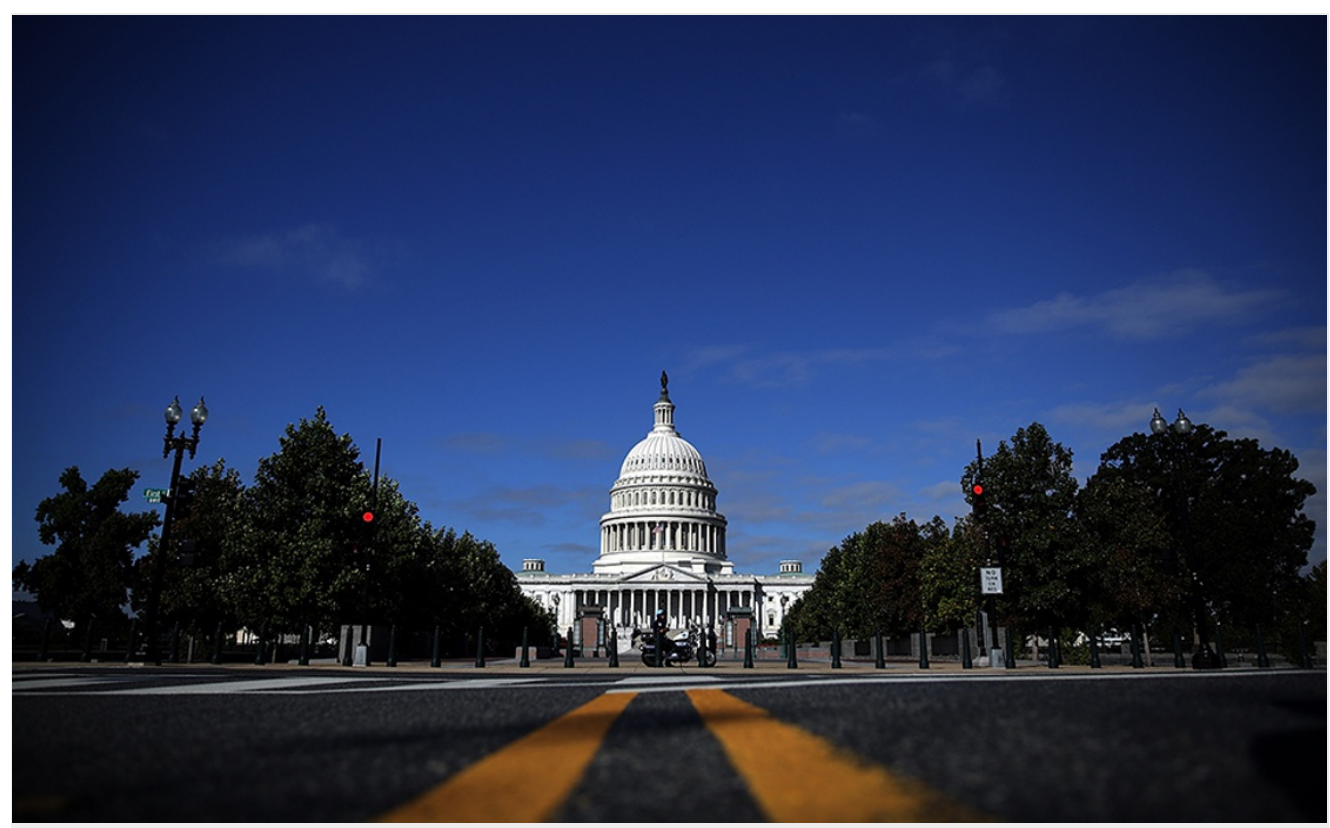

Wn MoNamee/Getty

Powerful Republicans in Congress are mulling proposals that would cut social-science funding.

Evan Bradley has spent 14 years studying linguistics. But his mastery of the relationship between music and tonal languages such as Mandarin Chinese was of little use during Bradley's recent trip to Washington DC, as he tried to decipher the lingo of bureaucrats in the US Congress. He was one of 70 social scientists who descended on Capitol Hill on 29 March in an attempt to convince politicians that social science deserves government support — despite a renewed push by leading Republicans to shrink research funding.

For social scientists such as Bradley, the stakes are high. US President Donald Trump has proposed sweeping cuts to major science agencies, including the National Institutes of Health and the Environmental Protection Agency. And the powerful chair of the House of Representatives' science committee, Texas Republican Lamar Smith, wants to shift $70 \%$ of the National Science Foundation (NSF) budget into just four research areas — mathematics and physical sciences, computing, engineering, and biology — and reduce support for the agency's social-science and geoscience divisions.

"In the past, l've done armchair activism - you know, 'hashtag activism'," says Bradley, who works at Pennsylvania State University's Brandywine campus in Media. But this year, he says, "I felt it was important to get involved on the ground."

His trip to Capitol Hill was organized by the Consortium of Social Science Associations (COSSA). For the past three years, the group has invited linguists, anthropologists, sociologists and political scientists from across the country in Washington DC, for a brief training session before a whirlwind day of meeting with members of Congress and their aides to advocate for science funding. This year, participation set a record: 70 researchers attended the training before fanning out to meet with 80 members of Congress.

\section{Baby steps}

For many of the participants, it was the first time they'd spoken to an elected official. Emily Beaulieu, a political scientist at the University of Kentucky in Lexington, met an aide to one of her state's two senators: Republican Rand Paul, who publishes frequent reports detailing government programmes that he considers wasteful. Science, including social science, is often a target.

During their meeting, Paul's aide said that the senator supports science "if it isn't wasteful", Beaulieu says. "Of course, sometimes you don't know what the application or significance of scientific research will be until it's done," she adds. 
Rebecca Eissler, a graduate student in political science at the University of Texas at Austin, met an aide to Smith. Given Smith's history with the social sciences, she didn't expect it to go well. At first, she says, the meeting was awkward, and the aide was non-committal. But when Eissler and her fellow researchers asked how they could help Smith's staff, the atmosphere improved. "We had a discussion about the merits of good science," says Eissler — who notes that she and the aide still disagree about what constitutes 'good science'.

Many of the proposals to cut funding for social science are familiar to research advocates, but have never managed to garner enough support to become law. Now the shifting political winds have given them new life. For example, Smith has long argued that the NSF should focus on science that supports the US national interest - and by his definition, that does not include social science. With Republicans now controlling the White House and both chambers of Congress, Smith's proposal could finally become reality.

That would be devastating for US anthropologists, for whom the NSF is a major source of research grants, says Ed Liebow, executive director of the American Anthropological Association in Arlington, Virginia.

And even some researchers who might benefit from such a plan say that they find it worrisome. "I don't think it's a good thing," says Scott Collins, an ecologist at the University of New Mexico in Albuquerque and a former NSF programme director. "We're not out here to eat our own. Science is interdisciplinary."

That message resonates with Beaulieu, who was inspired by her day of meetings with politicians. Social scientists "realize that we're a part of a broader research community", she says, "and we need to be heard".

Nature | doi:10.1038/nature.2017.21801 